\title{
Review of Rasayan Chikitsa according to the Srotas in geriatric disorders
}

\author{
Shlesha Dadasaheb Chandanshive* ${ }^{1}$, Paradkar Hemant ${ }^{2}$, Pathrikar Anaya ${ }^{3}$
}

1. P. G. Scholar,

2. Guide and Associate Professor,

3. Professor and HOD

Kayachikitsa Dept., APM'S Ayurved Mahavidyalaya, Sion, Mumbai, Maharashtra. -22

*Corresponding author: shleshac114@gmail.com

\begin{abstract}
Ageing is essentially a physiological phenomenon usually defined as the progressive loses of biological functions accompanied by decreasing fertility and increasing mortality with advancing age. I represents structural and functiond changes of an organism over its life spañ. Ayurveda considers ageing as biological nature of living being and believes in natural cycle of birth-senescence-deathrebirth as the very destiny of the life. Ayurveda Rasayan Therapy has given powerful contribution and rejuvenates the body and the mind.the present study explains Rasayan Chikitsa in various Geriatric Disorders according to Srotas mentioned in Ayurvedic texts.
\end{abstract}

Key words:- Ageing , Rasayan chikitsa, Strotas

\section{INTRODUCTION:}

- Ayurved has focused branch of medicine called Rasayan (Rejuvenation) which exclusively deals with the problems related to ageing and the methods to counter the same. Geriatrics or Jara Chikitsa or Rasayan Chikitsa in ayurveda is the method to control or to slow down the ageing process in the human being during the degenerative phase of one's life.

- Rasayan is normally advised during this degenerative phase which starts from around 45 yrs in both male and female. A holistic system like Ayurved a approaches this condition through two-fold-methods. One is radical approach in which it recharges the whole metabolic process of the body by eliminating the toxins from the body by three to four months rigorous and organized process known as Kuttipraveshika Rasayan. However, this process is seldom practiced due to the extreme intricacy of physiological process involved and the need for utmost care to be taken by physician and the subject including the environment where the treatment is done. Hence, the Kuttipraveshika remains as textual marvel of Ayurveda than practical 
process of contemporary relevance.

- The second approach of Ayurveda is Vataatapika Rasayan which can go along with normal day to day life. This type of rasayan is particularly important in current scenario as it has relatively easy mode of administration without any restrictive pre-conditions.

Aim

Review on Rasayan Chikitsa according to Srotas in Geriatrics Disorders.

\section{Objectives}

- To study Rasayan Chikitsa in various Geriatric Disorders according to Srotas.

- To study the hetu, lajshan of Srota dushti in Geriatric Disorders.

- To study Various Geriatrics Disorders.

\section{Review of literature}

\section{Pranvaha Srotas:-}

Vegvidharan,ruksha ahar sevan, excessive langhan,dhatukshaya causes Pranvaha Srotas dushti. Due to Pranvaha Srotas dushti,there is Hikka, Shwas seen in Geriactrics age group.

\section{Rasayan used in Pranvaha Srotas dushti:- \\ Pimpli,Bhallatak,Amalaki,Marich,Kasturi}

\section{Udakavaha Srotas :-}

Bhay, trushna veg vidharan, chinta causes Udakavaha Srotas dushti. Due to udakavaha srotas, there is Trushna seen in Geriactric age group.

Rasayan used in Udakavaha Srotas dushti:-All fruit juices

\section{Annavaha Srotas :-}

Aniyamit ahar sevan kal,ahitkar aahar sevan causes Aanavaha Srotas dushti. Due to Annavaha Srotas dushti, Mukhpak, Annabhilasha, Aruchi seen in this Geriatric age group.

Rasayan used in Annavaha Srotas dushti:- Panchkol especially marich ,Kapardik, Shankh Bhasma, Parpati kalp, Hing, Nagkeshar.

\section{Rasavaha Srotas :-}

Guru shit aahar sevan,aatisnigdha aahar sevan causes Rasavaha Srotas dushti. Due

Rasavaha Srotas dushti Pandu, rinkles, Karshya,Agnimandya weakness seen in this geriactrics age group.

Rasayan used in Rasavaha Srotas dushti:-Kharjurmanth, Lajamand, Guduchi, Yashtimadhu, Manjistha, Shounthi.

\section{Raktavaha Srotas :-}

Vidahi aahar sevan, Snigdha-Ushna ahar,drava ahar sevan causes Raktavaha Srotas dushti. Due to Raktavaha Srotas dushti,Gudpak, Mukhpak,Vyang, Pipliv, Tilkalak, Charmadal seen in Geriactric Group.

Rasayan used in Annavaha Srotas dushti:-Loha Bhasma,Gorechan, Guduchi, Bhrungaraj,Sariva, Manjistha,Aamalaki.

\section{Mamsavaha Srotas:-}


Abhishyandi ahar, guru sthul ahar ,divaswap causes Mamsavaha Srotas Dushti. Due to Mamsavaha Srotas dushti, Adhimamsa,Arbuda seen in Geriactric age.

Rasayan used in Mamsavaha Srotas dushti:-Suvarna Bhasma, Shudh Karaskar

\section{Medovaha Srotas:-}

Avyayam,divaswap,snigdha-guru-shit aahar sevan causes Medovaha Srotas dushti. Due to Medovaha Srotas dushti Sthulya, Excessive sweating, Madhumeha seen in Geriactrics age group.

Rasayan used in Medovaha Srotas dushti:-Guggulu,Shilajit, Patol, Musta, Guduchi, Kumbha.

\section{Asthivaha Srotas :-}

Excessive exercise, Aghat, vatakar ahar vihar, atichankraman causes Asthivahr Srotas dushti. Due to Asthivaha Srota dushti, Arthritis, Toothache, Dental problems seen in Geriactric group.

Rasayan used in Asthivaha Srotas dushti:-Aabha, Asthishrunkhala, Shallaki , Shankh Bhasma, Kukkutand twak Bhasma.

\section{Majjavaha Srotas:-}

Abhishyandi Ahar sevan, Virudhaahar sevan,Abhighat,Prapidan causes Majjavaha Srotas dushti. Due to Majjavaha Srotas dushti,Bhram, Tamah Pravesh, Murccha,Sandhi pradeshi shul shoth seen.

$\begin{aligned} & \text { Rasayan used in } \begin{array}{c}\text { Majjavaha } \\ \text { Bushti:-Roupya }\end{array} \\ & \text { Bhasma, }\end{aligned}$ Vacha,
Bhrungaraj,
$\begin{aligned} & \text { Jatamunsi. } \\ & \text { Brahmi,Shankhpushpi, }\end{aligned}$

10.Purishvaha Srotas :-
Purishved dharan,Ajirnashan,Adhyashan, Agnimandya, Atikrushata causes Purishvaha Srotas dushti. Due to Purishvaha Srotas dushti,Sakashta malpravrutti,sashul malpravrutti, constipation seen.

Rasayan used in Purishvaha Srotas dushti:-Kutaj, Bilva, Haritaki, Suvarnapatri. Goghrut

\section{Mutravaha Srotas :-}

Mutraveg dharan,excessive water intake, less water intakecauses Mutravaha Srotas dushti. Due to Mutravaha Srotas dushti, Bahumutrata,Varanvar mutra pravrutti,Mutrakrucchaseen.

Rasayan used in Mutravaha Srotas dushti:-Shilajit, Gukshur, Punarnava, Varun, Pashanbhed.

\section{Swedavaha Srotas :-}

Excessive walking, Bhay, Chinta, excessive exercise causes Swedavaha Srotas dushti. Due to Swedavaha Srotas dushti, dryness of skin or excessive sweating seen .

\section{Rasayan used in Swedavaha Srotas dushti:-Vatsanabh kalp, Nag-vang Bhasma.}

\section{Discussion:-}

As per as the Ayurvedic principles, the Ageing is Swabhava or natural phenomena of life. Charaka Samhita mentions that functional diminution of Dhatu, Oja, Strength of sense organs, power of cognition, strength of body and valor are gradually decreasing during old age, so, the effect of therapy of rasayana affords comprehensive physiologic and metabolic restoration and gives important 
contribution to minimize these difficulties including mental development and resistance against diseases among elders. Because of Rasayan drugs and therapeutic measures act on Dhatus, Agni, Srotas and produce healthy tissues development in the body and in turn it provide a person longevity, immunity, resistance against diseases, strength, happiness and intellect promotion in the mind.

\section{Conclusion:}

Hence it can be concluded that strotas parikshan plays a important role while treating patients with rasayan chikitsa.

\section{References:}

1. Shastri, Ambikadutta Susruta Samhita, Ayurveda-Tattva-

Sandipik Hindi Commentry by Chaukhabha Sanskrit Sansthap Varanasi (2001).

2. Dravvyagun Vidnyan- Dr. J. L.N. Sastry, Edition reprint (2009).

3. Bhaiyshyajjya RatnavaliProff.Siddhinandan Mishra,1st Edition(2005). Page No.600 - 610.

4. Bhavprakash Madhyam Khand Edited with the Vidyotni Hindi
Commentary by Bhishagratna

Pandit Shree Brahma Shankar Mishra. $8^{\text {th }}$ Edition-(2003). Page No. 277-284.

5. Madhavakara, madhava nidhanam volume1, With Madhukosh commentary, by Dr. Brahmanand Tripathi.chaukhamba prakashan, edition 2010. Page No. 575.

6. Shri Chakrapanidattavirachittah Chakradatta- Panditraj vaidhya Ravidatta Shastri, Padarthbodhini Hindi Commentary, Chaukhamba Prakashan- Edition (2000). Page No. 118.

7. Yogratnakar- By Vaidya Laxmipathy Shastri - Chaukhamba Prakashan, Edition (2012), Page No. 564-565, 569.

8. Ayurveda Sarsangrah.- Edited by Shri Baidhanath Ayurveda Bhawan ltd. Ilahabad- (2003). Page No.523524.

\section{Cite article:}

Review Of Rasayan Chikitsa According To The Srotas In Geriatric Disorders Shlesha D. Chandanshive, Paradkar Hemant, Pathrikar Anaya Ayurlog: National Journal of Research in Ayurved Science- 2018; (6)(6): 1-4 